\title{
The curious commentary on the citation practices of Avner Greif
}

\author{
Avner Greif
}

Received: 15 September 2009 / Accepted: 15 September 2009 / Published online: 29 September 2009

(C) Springer Science+Business Media, LLC 2009

\begin{abstract}
Rowley's (Public Choice 140:275-285, 2009) claim that I have "expropriated" (p. 276) intellectual property rights from Professor Landa by insufficiently citing her works is vacuous. It failed, among other faults, to recognize the substantive distinction between the lines of research pursued by Professor Landa and myself. Her analysis of trust is preferencesbased while my analysis is beliefs-based. We talk about similar issues but what we say is very different.
\end{abstract}

Keywords Ethnically homogeneous middleman group · Maghribi traders' coalition · Economics of trust $\cdot$ Economics of identity $\cdot$ Priority citations $\cdot$ Reputation

Rowley (2009) has wrongly claimed that "Avner Greif, through his citation practices, has denied Janet Landa her full intellectual property rights with respect to her contributions to the economic analysis of trust and identity" (p. 275). This claim is unsubstantiated and incorrect for many reasons. To keep this response short, however, it focuses on the core issue Rowley (2009) ignores; the substantive distinction between the research pursued by Professor Landa and myself. Her analysis of trust is preferences-based while my analysis is beliefs-based. We talk about similar issues but what we say is very different. I gave credit where it was due.

Neither Professor Landa nor I have claimed to initiate the study of the relations between trust, exchange and merchants' groups. For example, in her paper, "A Theory of Middleman Minorities," Bonacich (1973) tried "to explain the development and persistence of the form ... [and what affects] the solidarity and economic activity of the ethnic group" (p. 583). She noted that her theory might apply to middleman minorities such "as the Chinese in South East Asia, Jews in Europe, and Indians in East Africa" (p. 583).

Professor Landa has made valuable contributions since publishing her first paper (1981). She argued that trust is embodied in preferences, depends on social relations and progressively declines with social distance. One trusts his family more than members of his extended family and trusts his clansmen even less. Ethnicity and its code of ethics delineate an

\footnotetext{
A. Greif $(\bowtie)$

Department of Economics, Stanford University, Stanford, CA 94305, USA

e-mail: avner@stanford.edu
} 
important boundary of social relations and ethnic groups are therefore an important conduit for exchange in the absence of the law. Rowley (2009) summarized Professor Landa's thesis. "A cost-minimizing middleman, under conditions of contract uncertainty, will choose trading partners with shared and easily identifiable kinship and ethnic characteristics because the Confucian ethic of reciprocity is embedded in these close kinship/ethnic relations" (p. 277).

My research has been motivated by observed trust between merchants and overseas agents in medieval trade. The literature on this topic (e.g., Sombart 1953) has also argued that preferences-based trust within kinship groups mitigated agency problems. I naturally cited this preferences-based research given its priority and my interest in medieval trade. I noted that "scholars have examined the establishment of "trust" relations among traders, focusing in particular on the role of social control systems and ethics. W. Sombart pointed out the importance of relationships within "natural groups," such as clans and tribes. ... Following Max Weber (e.g., 1927), many scholars have stressed the role of ethics in surmounting contractual problems, emphasizing either implicitly or explicitly altruism..." (Greif 1989, p. 858).

Rowley (2009) fails to note that my analysis did not follow the preferences-based line of research, although I have made this distinction explicit. "It is important to note that the Maghribi traders did not ... represent a "natural" group, which binds together individuals in all (or at least most) important aspects of their lives. The bonds of a natural group usually discourage dishonest conduct" (Greif 1989, p. 862). The observed " 'trust' did not reflect a social control system or the internalization of norms of behavior" (Ibid., p. 881).

The theory I developed is beliefs-based. It focused on the role of beliefs in rendering honesty an equilibrium outcome among self-interested individuals, irrespective of kinship. “Observed 'trust' [among the Maghribis] reflects a reputation mechanism among economic self-interested individuals" (Ibid., pp. 858). ${ }^{1}$ Beliefs in harsh economic retaliation following misconduct rendered effective a reputation mechanism that supported credible commitment to honesty and thus trust. These beliefs induced "an agent [to] remain honest out of desire to retain his position as an agent” (Ibid., p. 867).

In this beliefs-based framework ethnic groups, social networks, business associations, and credit bureaus are conduits of the information required for an effective reputation mechanism. In particular, "the common religious-ethnic origin of the [Maghribi] traders provided the natural boundaries for the ... [group] and served as a signal where information regarding past conduct could be obtained, while the commercial and social ties ... served as a network for the transmission of information" (Ibid., p. 882). The traders' group and their economic institution were therefore mutually constitutive. The "information-transmission mechanism generated by the social structure - the Maghribi traders group - supported the operation of an economic institution ... which promoted organizing agency relations only among members of this social structure, ... and thus ... preserve their social structure, their distinct identity within the Jewish world" (Ibid.).

Professor Landa's work and mine are therefore substantially different. She has made important contributions to the study of trust as exogenous, inherent in one's preferences, and conditional on social relations. My work considers trust as endogenous, dependent on selfenforcing beliefs about others' responses, and conditional on the information and knowledge

\footnotetext{
${ }^{1}$ The page also notes the relations between the two frameworks. "By establishing ex ante a linkage between past conduct and future utility stream, an agent could acquire a reputation as honest, that is, he could credibly commit himself ex ante not to breach a contract ex post." "Social control system and ethics mechanisms may constitute such a linkage. These mechanisms can thus be incorporated into the present approach." Beliefs concerning others' unobservable preferences are crucial in such linkages.
} 
necessary for such beliefs to be self-enforcing. In short, Professor Landa has focused on preferences as underpinning trust; I have focused on the role of beliefs. I may have failed to make this distinction crystal clear and update my references. This distinction, nevertheless, is among the many reasons that Rowley's claim is incorrect.

As a matter of fact there is a positive correlation between the publication of my work and citations to Professor Landa's work. Landa (1981) is her "first and most important paper on the economic of trust" (Rowley 2009, p. 277). Almost nine years later I published my first paper (Dec. 1989). Comparing the number of citations to Landa (1981) prior to and following my first publication is revealing. There were six times more citations in the second period. ${ }^{2}$ Citation levels remained high in subsequent years and the number of citations in economics has similarly increased in each of these three sub-periods. ${ }^{3}$ My students and I have continuously contributed to this record including, as is easy to verify using Google book search, references to her works on pages 70 and 88 in my recent book (Greif 2006). The assertion in Rowley (2009, p. 282) that "Janet Landa's name and publications are absent from" the text of this book is obviously baseless and incorrect. Its broader claim is similarly vacuous. Scholarship is not necessarily a zero-sum game.

\section{References}

Bonacich, E. (1973). A theory of middleman minorities. American Sociological Review, 36(Oct), 583-594.

Greif, A. (1989). Reputation and coalitions in medieval trade: evidence on the Maghribi traders. Journal of Economic History, 49(4), 857-882.

Greif, A. (2006). Institutions and the path to the modern economy: lessons from medieval trade. Cambridge: Cambridge University Press.

Landa, J. T. (1981). A theory of the, ethnically homogeneous middleman group: an institutional alternative to contract law. The Journal of Legal Studies, 10, 348-362.

Rowley, C. K. (2009). The curious citation practices of Avner Greif: Janet Landa comes to grief. Public Choice, 140, 275-285.

Sombart, W. (1953). Medieval and modern commercial enterprise. In F. C. Lane \& J. C. Riemersa (Eds.), Enterprise and Secular Change. Chicago: Homewood.

Weber, M. (1927). General economic history, trans. by F. H. Knight. New York.

\footnotetext{
${ }^{2}$ Specifically, the nine years after 1991 (inclusive).

3 "Social Science Citations Index" (SSCI), July 29, 2009. Without self-citations. I relied on the SSCI (automatic) calcification of citations to fields. Rowley (2009) claims that Professor Landa's "writings on the economic analysis of trust and identity have received no citations from mainstream economists" (p. 283) but does not elaborate on the basis for this conclusion.
} 